\title{
Bad boys: how criminal identity salience affects rule violation
}

Cohn, Alain ; Maréchal, Michel André ; Noll, Thomas

\begin{abstract}
We conducted an experiment with 182 inmates from a maximum security prison to analyze the impact of criminal identity salience on cheating. The results show that inmates cheat more when we exogenously render their criminal identity more salient. This effect is specific to individuals who have a criminal identity, because an additional placebo experiment shows that regular citizens do not become more dishonest in response to crime-related reminders. Moreover, our experimental measure of cheating correlates with inmates' offences against in-prison regulation. Together, these findings suggest that criminal identity salience plays a crucial role in rule violating behaviour.
\end{abstract}

DOI: https://doi.org/10.1093/restud/rdv025

Posted at the Zurich Open Repository and Archive, University of Zurich ZORA URL: https://doi.org/10.5167/uzh-118356

Journal Article

Accepted Version

Originally published at:

Cohn, Alain; Maréchal, Michel André; Noll, Thomas (2015). Bad boys: how criminal identity salience affects rule violation. Review of Economic Studies, 82(4):1289-1308.

DOI: https://doi.org/10.1093/restud/rdv025 
University of Zurich

Department of Economics

Working Paper Series

ISSN 1664-7041 (print)

ISSN 1664-705X (online)

Working Paper No. 132

\section{Bad Boys:}

How Criminal Identity Salience Affects Rule Violation

Alain Cohn, Michel André Maréchal and Thomas Noll

Revised version, May 2015 


\title{
Bad Boys: How Criminal Identity Salience Affects Rule Violation*
}

\author{
Alain Cohn, Michel André Maréchal and Thomas Noll
}

May 2015

Review of Economic Studies, forthcoming

\begin{abstract}
We conducted an experiment with 182 inmates from a maximum security prison to analyze the impact of criminal identity salience on cheating. The results show that inmates cheat more when we exogenously render their criminal identity more salient. This effect is specific to individuals who have a criminal identity, because an additional placebo experiment shows that regular citizens do not become more dishonest in response to crime-related reminders. Moreover, our experimental measure of cheating correlates with inmates' offenses against in-prison regulation. Together, these findings suggest that criminal identity salience plays a crucial role in rule violating behavior.
\end{abstract}

JEL classification: K00, C93, K14, K42, Z10

Keywords: Dishonesty, Identity, Crime, Prison, Experiment.

* Cohn: University of Chicago, Booth School of Business, 5807 South Woodlawn Avenue, Chicago, IL 60637, USA, email: alain.cohn(at)chicagobooth.edu. Maréchal: University of Zurich, Department of Economics, Bluemlisalpstrasse 10, CH-8006 Zurich, Switzerland, email: michel.marechal(at)econ.uzh.ch. Noll: Swiss Prison Staff Training Center, Avenue Beauregard 11, CH-1700 Freiburg, Switzerland, email: noll(at)prison.ch. We thank Milena Brunner, Marion Cohn, Markus Hauzenberger, Bigna Ruppen, Giuseppe Ugazio and Sophia Zügel for providing excellent research assistance and David Huffman for inspiring discussions. We are grateful Botond Köszegi, two anonymous referees, Henk Aarts, John Antonakis, Dan Ariely, Daniel Benjamin, Sam Bowles, Alexander Cappelen, Daniel Chen, Stefano DellaVigna, Jérôme Endrass, Ernst Fehr, Nicola Gennaioli, Herb Gintis, Sally Gschwend, Dan Kahan, Martin Killias, Ilyana Kuziemko, Richard McAdams, Nick Netzer, Jesse Shapiro, Bertil Tungodden, Glenn Walters and Roberto Weber, as well as the audiences at Invitational Choice Symposium Erasmus, SITE Stanford, ESA Chicago, University of Chicago Booth, Deception, Incentives \& Behavior Symposium San Diego, MPI Bonn, WZB Berlin, THEEM Konstanz, University/ETH Zurich, and Forensic Psychology \& Psychiatry Canton Zurich for helpful feedback. We acknowledge the support of the Gottlieb Duttweiler Institute. Correspondence to: Cohn and Maréchal. 


\section{Introduction}

Crime imposes substantial costs on society. For example, it has been estimated that the annual burden of crime for the United States ranges between one and two trillion US dollars (Ludwig 2006, Anderson 1999). Understanding why people commit crime and violate the law is therefore of key interest for policy makers and researchers. According to the seminal work of Becker (1968), a person's decision to commit crime is based on weighing the expected material benefits against the punishment costs. ${ }^{1}$ A longstanding sociological and psychological literature argues, however, that in addition to rational cost-benefit calculations, the decision to commit or refrain from crime also crucially depends on people's moral and self-image considerations (see Anderson 2000, Kaplan 1975, Reckless 1967, Becker 1963, or Cohen 1955). ${ }^{2}$ These views line up with recent theoretical approaches in law and economics incorporating identity and norms into decision making (see Acemoglu and Jackson 2014, Bénabou and Tirole 2011a,b, Posner 2009, McAdams and Rasmusen 2007, and Akerlof and Kranton 2000). For example, people in Akerlof and Kranton's model have multiple social identities (e.g., based on gender, ethnicity, or occupation) that are tied to norms prescribing how one should behave. Identities may influence behavior because individuals experience disutility if their behavior deviates from what their identities prescribe.

Applying identity theory to the context of crime, we propose that deviant people have a moral and a criminal identity; these identities differ in the extent to which they impose rule compliance. Rule violating behavior inflicts psychological costs on the moral identity (e.g., Abeler et al. 2014, Kartik 2009, or Gneezy 2005). Whenever these costs are sufficiently large relative to the net benefit of rule violation, the moral identity prescribes compliance. In contrast, the criminal identity does not suffer from moral costs (or suffers to a much lesser extent) and thus prescribes, in accordance with Becker's model, breaking rules whenever it pays off. As a consequence, stronger criminal identification should lead to more rule violating behavior. While several correlational studies from criminology indeed report a positive relationship between survey measures of criminal identity and deviant behavior (see Gendreau et al. (1996) for a meta-analysis), these studies are not able to disentangle whether criminal identity has a causal impact on rule violating behavior or whether rule violating behavior leads to stronger criminal identification.

Identifying the causal influence of criminal identity on rule violating behavior is

\footnotetext{
${ }^{1}$ See Draca and Machin 2015, Chalfin and McCrary 2014, or Nagin 2013 or for excellent reviews of the empirical literature.

${ }^{2}$ These theories initiated an active literature in criminology developing psychological scales of criminal self-concept (e.g., Simourd and Olver 2002).
} 
challenging. A simple comparison of criminals and non-criminals is problematic because criminals and law-abiding citizens may differ in many dimensions that are difficult to control for, such as financial background, life prospects, or opportunity costs. ${ }^{3}$ Instead, we experimentally manipulate the saliency of criminal identity, which circumvents the aforementioned problems involved in the comparison of people with different levels of criminal identification. Identity theory posits that the extent to which individuals' criminal and moral identities guide their behavior depends on the relative weight (i.e., salience) they attach to each identity at a given moment (see also Benjamin et al. 2010, 2013). Consequently, a temporary boost in criminal identity salience reveals the identity's marginal behavioral effect.

To test whether criminal identity salience triggers rule violating behavior, we conducted an experiment with 182 inmates from the maximum security prison Pöschwies, Switzerland's largest penitentiary for male adults. We opted for this unusual subject pool because prison inmates have plausibly a distinct criminal self-concept due to their extensive histories of criminal misconduct (e.g., see Lerman 2009 or Walters 2003). In our experiment, we randomly increased the saliency of criminal identity in half of the participants using embedded survey questions that reminded them of the fact that they are incarcerated criminals (e.g., "What were you convicted of?"). The other half of the participants served as the control group and answered questions unrelated to their criminal identity (e.g., "How many hours per week do you watch television on average?"). The participants subsequently performed a simple coin tossing task, which allows us to measure their dishonesty as a form of rule violating behavior. The rules of the task required subjects to flip ten coins and report the outcomes on paper. They were allowed to keep every coin for which they reported "heads", creating a monetary incentive to break the rules and misreport the coin flips. Because participants were unobserved, they could easily hide behind chance and thus did not have to fear any punishment. We are nevertheless able to measure cheating at the group level, as we know the distribution which should result from honest reporting. ${ }^{4}$

The results show that a significant share of the inmates cheated. On average, they reported heads for 60 percent of the coin flips in the control condition. This is significantly above chance and approximates 20 percent of coin flips being misreported. ${ }^{5}$ However, inmates became even more dishonest when their criminal identity was rendered more

\footnotetext{
${ }^{3}$ See Birkeland et al. (forthcoming), Khadjavi and Lange (2013), and Chmura et al. (2013) for studies comparing distributive preferences and cooperation in criminals and non-criminals.

${ }^{4}$ See Fischbacher and Föllmi-Heusi (2013) or Houser et al. (2012) for similar approaches to elicit dishonest behavior.

${ }^{5}$ In line with previous research on honesty our subjects did not take full advantage of cheating opportunities (Ariely 2012).
} 
salient. In the criminal identity treatment, they reported 66 percent of heads which corresponds to 32 percent of coin flips being misreported. Thus, the higher saliency of criminal identity increased the frequency of misreporting by 60 percent. Using administrative data, we further show that behavior in the coin tossing task correlates with inmates' offenses against in-prison regulation (e.g., aggression against others, use of illegal drugs, or weapon possession), suggesting that the coin tossing task provides an externally valid measure of rule violating behavior. Half a year after the main study, we conducted a further experiment in the same prison which serves as a manipulation check. Based on an implicit measure of criminal cognition we find that the criminal identity questions enhanced the mental accessibility of crime-related thoughts. This indicates that the treatment manipulation worked as intended.

We discard several alternative explanations to a criminal identity effect. For example, one could argue that the questions might have triggered negative emotions and arousal because they reminded prisoners about their deeds or the social injustice of incarceration (Sherman 1993). Such an emotional reaction could potentially undermine honesty. However, we demonstrate that the criminal identity questions did not influence emotions, and that the correlations between emotions and cheating are insignificant. Furthermore, the saliency of criminal identity might have influenced inmates' risk attitudes (Benjamin et al. 2010). If inmates erroneously believed that cheating was individually detectable, a decrease in risk aversion could also explain a higher cheating rate in the criminal identity treatment. We therefore elicited inmates' risk attitudes and tested whether they are correlated with earnings in the coin tossing task. The correlation is close to zero and statistically insignificant, suggesting that a change in risk attitudes is unlikely to drive the priming effect.

Finally, the mere exposure to crime-related content, rather than the salience of criminal identity, could have triggered dishonest behavior in the criminal identity treatment. We therefore conducted an additional placebo experiment with "regular" citizens in order to test whether the priming effect is specific to people who have a criminal identity. We recruited 193 male citizens from the general population and administered the same survey. Before answering the six crime-related or control questions, participants memorized a short text profile describing either a criminal or a non-criminal person. We created these profiles using representative answers from the prisoners in the criminal identity, respectively the control treatment. Subjects subsequently answered the same questions as the prisoners from the perspective of the person described in the profile. The results show that the criminal profile treatment had no significant influence on cheating. If anything, the effect goes in the opposite direction: the fraction of misreported coin flips 
drops from 14 percent in the control condition to 10 percent in the criminal condition. Together, the three studies suggest that criminal identity salience promotes rule violating behavior.

Our results contribute to a growing literature studying the role of identity in economic decision making (e.g., Akerlof and Kranton 2000, Fang and Loury 2005, or Bénabou and Tirole 2011a). The empirical literature mostly analyzed whether people discriminate between in- and outgroup members (e.g., Hoff and Pandey 2006, Charness et al. 2007, Chen and Li 2009, Goette et al. 2012, or Kranton et al. 2012). One of the few exceptions is the study by Benjamin et al. (2010) who used a similar approach to ours and analyzed the influence of ethnic and gender identity salience on risk and time preferences. A more recent study by Bertrand et al. (2013) illustrates that gender identity norms influence a wide range of economic and social outcomes. They find that the norm "wives should not earn more than their husbands" helps explain female labor force participation, divorce, and the division of home production within US households. ${ }^{6}$ We add to this literature by providing causal evidence on the impact of identity salience on dishonest behavior. In this sense our results are also relevant for the rapidly expanding literature on the determinants of dishonesty (e.g., Cohn et al. 2014, Balafoutas et al. 2013, Fischbacher and Föllmi-Heusi 2013, Pruckner and Sausgruber 2013, Shalvi et al. 2011Mazar et al. 2008, or Gneezy 2005, ).

Our study may also be relevant for the problem of recidivism. Estimates from the United States, for example, indicate that more than four out of ten released inmates are rearrested within three years (Pew Center on the States 2011). Our results suggest that one factor that may contribute to recidivism are so-called collateral consequences of conviction. These are punishments that come in addition to the actual sentence and include deprivation of civil rights, loss of professional licenses, or restricted access to public benefits (Travis 2002). Besides deterring people, collateral sanctions may increase the probability of recidivism by reminding convicts of their criminal identities.

\section{An Experiment Behind Bars}

\section{Design}

We conducted our experiment in the maximum security prison Pöschwies - Switzerland's largest penitentiary for male adults. A total of 182 inmates participated in the experiment. The majority of them were convicted of violent crimes (30\%), followed by drug

\footnotetext{
${ }^{6}$ See also Alesina et al. (2013) on the historical origins of today's gender identity norms.
} 
related crimes (26\%), property crimes $(24 \%)$, sex crimes (15\%), and other types of crime $(5 \%)$. Almost two third (62\%) were repeat offenders. Participants had been incarcerated for 2.7 years on average, with a minimum of 26 days and a maximum of 22.5 years. $^{7}$

We sent an invitation for a survey study from the University of Zurich to all inmates. Participants were assured of confidentiality and that their individual data would not be revealed to the prison authorities. Interested participants could choose their preferred survey language among four options: German, English, Italian, and French. A few days later, participants received an envelope containing the survey (see online appendix), and a second smaller envelope they were instructed to open at a later point in time. We ensured that the inmates completed the survey in private without being disturbed by guards or other inmates. Inmates from single cells received the survey overnight, and those who shared their cell with another inmate completed the survey while their cellmate was working. ${ }^{8}$ The experiment was conducted within 24 hours in order to minimize the possibility of cross-talk among inmates.

The first part of the survey contained filler questions on subjective wellbeing and standard demographics. The second part comprised our key experimental manipulation. We randomly primed half of the participants with their criminal identity by asking them six questions that reminded them of the fact that they are incarcerated criminals (e.g., "What were you convicted for?" or "How long have you been in custody?"). ${ }^{9}$ The other half of the participants served as the control group and answered six questions unrelated to their criminal identity (e.g., "What is your favorite activity when you do not have to work?" or "How many hours per week do you watch television on average?"). These six questions were the only difference between the criminal identity and the control treatment. ${ }^{10}$ Immediately after the priming, participants were asked to indicate their current emotional state using non-verbal Self-Assessment Manikins (Bradley and Lang 1994). ${ }^{11}$ This allows us to identify potential emotional reactions to the priming questions.

Towards the end of the survey, subjects were instructed to open the second envelope which contained ten coins, each worth 0.5 Swiss francs (or 0.55 US dollars). The rules

\footnotetext{
${ }^{7}$ See Table A1 in the appendix for further descriptive statistics of our sample. Table A4 in the appendix shows descriptive statistics from the whole prison population in the year of the experiment. The composition of participants is very similar to that of the total prison population.

${ }^{8}$ Working hours are staggered for inmates in double cells. Each inmate works for half a day.

${ }^{9}$ Priming is a method developed in psychology and refers to the activation of mental representations through situational cues (Bargh and Chartrand 2000, Shih et al. 1999, or LeBoeuf et al. 2010). Priming is now increasingly used in economics (e.g., Callen et al. forthcoming, Hoff and Pandey forthcoming, Benjamin et al. 2010, 2013, or Chen et al. 2010).

${ }^{10}$ In order to ensure a ceteris paribus comparison of the two treatments, we also matched the answer formats of the two sets of questions.

${ }^{11}$ These measures have been shown to be consistently correlated with different physiological measures, such as heart rate and facial muscle contraction (Bradley and Lang 2000).
} 
required the participants to flip the coins sequentially and to report the outcome on paper. They were allowed to keep every coin for which they reported "heads". If they flipped tails, they had to put the coin back into the envelope together with the survey, which had to be handed over to the guards on the next morning. Participants thus had a monetary incentive to cheat by misreporting the outcome of their coin flips. The stake size was sizable for the participants, considering that the maximum payoff matched their hourly wage in prison. Because participants could hide behind chance, it is impossible to determine with certainty whether an individual cheated or not. They therefore did not have to fear any adverse consequences from cheating. However, we are able to infer the extent to which participants in different groups cheated by comparing the empirical distributions of reported heads with the binomial distribution implied by honest behavior. Moreover, assuming that none of the participants cheated to his disadvantage - reporting tails when the actual outcome was heads - we are able to calculate the percentage of coin flips that are misreported (see also Houser et al. 2012). Let $h$ be the percentage of reported heads and $m$ the percentage of coin tosses being misreported. The percentage of reported heads is therefore determined by

$$
h=m * 1+(1-m) * 0.5=0.5 *(1+m) .
$$

If a participant cheats, he reports heads with probability 1. However, honest reporting implies that heads occurs only with probability 0.5 . We can thus characterize the percentage of coin tosses that are misreported by

$$
m=2 * h-1 .
$$

The last column of Table A1 in the appendix reports whether there are any systematic differences between participants in the two treatment conditions and serves as a randomization check. The background characteristics appear well-balanced across treatments. There are no significant differences between groups in length of sentences, disciplinary offenses, re-offending status, age, $\operatorname{cognitive~skills~}{ }^{12}$, risk attitudes, or assignment to prison section. Only the fraction of inmates in the conviction category "Other" is significantly lower ( $\mathrm{p}<0.05, \chi^{2}$ test) in the criminal identity treatment. Treatment differences in the number of years in prison ( $\mathrm{p}=0.100$, rank-sum test) and the share of inmates who completed compulsory school ( $\mathrm{p}=0.095, \chi^{2}$ test) are marginally significant. These marginal differences do not occur more frequently than chance would dictate. We nevertheless control for all three variables in our regression analysis.

\footnotetext{
${ }^{12}$ Cognitive skills were elicited using Frederick's (2005) cognitive reflection test.
} 


\section{Framework and Hypotheses}

We derive our hypotheses by adapting the identity framework from Benjamin et al. (2010). We assume that inmates have a criminal identity and a moral identity. These identities prescribe different behaviors in the coin tossing task. As a consequence, an internal conflict arises over appropriate behavior. We begin by formalizing the behavior prescribed by the moral identity.

For the moral self, we assume that the decision to cheat depends on personal benefits and expected punishment (Becker 1968), as well as psychological costs of cheating (e.g., Ellingsen and Johannesson 2004, Gneezy 2005, Charness and Dufwenberg 2006, Mazar et al. 2008, Kartik 2009, or Abeler et al. 2014). ${ }^{13}$ Let $x_{i} \in[0,10]$ denote the number of heads reported by inmate $i$ and $x_{0}$ be his true number of tossed heads. The moral identity's prescribed action $x_{m}$ is derived from maximizing the following utility function:

$$
\max _{x_{i} \in[0,10]} E U_{i}\left(x_{i}\right)=(1-p) x_{i}-p\left[\mathbb{1}_{x_{i} \neq x_{0}} f-\left(1-\mathbb{1}_{x_{i} \neq x_{0}}\right) x_{i}\right]-\lambda\left(x_{i}-x_{0}\right)^{2},
$$

where $p$ is the monitoring probability and $f$ the fine imposed when caught cheating, i.e., $x_{i} \neq x_{0} . \quad \lambda$ denotes the psychological costs of cheating. Given that in our context the probability of monitoring is zero, i.e., $p=0$, the decision to cheat reduces to a tradeoff between monetary gains and psychological costs of cheating. Solving the maximization problem yields the moral identity's optimal action $x_{m}=x_{0}+\frac{1}{2 \lambda}$, which depends on the true outcome $x_{0}$ and the psychological costs of cheating $\lambda$. The larger the psychological costs, the more $x_{m}$ corresponds to the true outcome $x_{0}$.

In contrast to the moral identity, we assume that cheating imposes no psychological costs on the criminal identity. Consequently, the action prescribed by the criminal identity $x_{c}$ is derived from maximizing the following utility function:

$$
\max _{x_{i} \in[0,10]} E U_{i}\left(x_{i}\right)=(1-p) x_{i}-p\left[\mathbb{1}_{x_{i} \neq x_{0}} f-\left(1-\mathbb{1}_{x_{i} \neq x_{0}}\right) x_{i}\right]
$$

Given a monitoring probability of zero, the utility of the criminal identity is maximized if heads is reported ten times, i.e., $x_{c}=10$. Thus, the criminal identity prescribes cheating to the full extent. We further assume that a criminal person maximizes a utility function that is a convex combination of the prescribed actions of his criminal identity and moral identity. Deviating from the prescribed actions causes disutility. A

\footnotetext{
${ }^{13}$ Note that we use a reduced-form representation of lying costs and do not discriminate between whether these costs arise from internal (e.g., self-image concerns) or external regulatory processes (e.g., social image concerns).
} 
criminal's maximization problem can thus be characterized as follows:

$$
\max _{x_{i} \in[0,10]} U_{i}=-w(s)\left(x_{i}-x_{c}\right)^{2}-(1-w(s))\left(x_{i}-x_{m}\right)^{2}
$$

where $0 \leq w(s) \leq 1$ is the weight placed on the criminal person's criminal identity, and $1-w(s)$ is the relative importance of his moral identity. We assume that $w(0)=0$ and $w^{\prime}>0 . s$ is the current strength of the criminal identity and has a permanent component $\bar{s}$, which may differ between individuals. Environmental cues or primes can make the criminal identity temporarily salient by a factor $\epsilon$ (i.e., $s=\bar{s} \cdot \epsilon$ ), where $\epsilon$ can take any value between 0 and 1 . A value of zero means that the criminal identity is not at all salient, while a value of one means that the criminal identity is fully salient. ${ }^{14}$ Inserting the preferred actions $x_{c}$ and $x_{m}$ into equation (5) and solving the maximization problem gives the following optimal action for inmate $i$ :

$$
x_{i}^{*}=w(s) \cdot 10+(1-w(s))\left(x_{0}+\frac{1}{2 \lambda}\right) .
$$

The optimal action of a criminal with identity considerations is the weighted average of the prescribed actions of his criminal identity and moral identity. By inducing an inmate to think about his criminal background in our experiment, we increase the current strength $s$ of his criminal identity by a factor $\epsilon$ and therefore augment the decision weight attached to his criminal identity. According to equation (6), his optimal action $x_{i}^{*}$ shifts toward the action the criminal identity prescribes which is $x_{c}=10$. This leads to the following hypothesis:

Hypothesis: Inmates, on average, report more successful coin flips in the criminal identity treatment than in the control treatment.

Note that this prediction only applies to individuals who have a criminal identity. If a person does not have a criminal identity (i.e., $\bar{s}=0$ ), crime-related primes do not lead to more cheating because $s=\bar{s} \cdot \epsilon=0$. Consequently, our framework predicts that non-criminals will not report more successful coin flips if they are induced to think about crime. We will return to this point when we discuss our placebo experiment with regular citizens.

\footnotetext{
${ }^{14}$ Given that our subjects live behind bars their criminal identity may already be salient to some extent in the control treatment (i.e., $\epsilon>0$ ). On the other hand, it seems also plausible that our subjects distract themselves and do not think permanently about the fact that they are incarcerated criminals (i.e., $\epsilon<1$ in the control group). The more salient criminal identities are in the control condition, the less likely we will find a treatment effect.
} 


\section{Experimental Results}

We outline our results in four steps. First, we examine the impact of criminal identity salience on cheating. Second, we validate our experimental measure of cheating by showing that behavior in the coin tossing task is correlated with inmates' offenses against in-prison regulation. Third, we analyze data from an additional experiment, which provides a manipulation check for the identity priming. Finally, we present the result from a placebo experiment conducted with subjects from the general population and test whether the priming effect is specific to criminals.

\section{Criminal Identity and Cheating}

The results from the coin tossing task show that many of the inmates cheated. On average, they reported heads for 63 percent of the coin flips, which is significantly above chance (95\% confidence interval: $60 \%, 66 \%{ }^{15}$ ). Assuming that none of the prisoners cheated to his disadvantage - reporting tails when the actual outcome was heads - we estimate that 26 percent of the coin flips were misreported (see Equation 2).

Panel A of Figure 1 shows the binomial distribution of the number of heads which should theoretically result if everyone was honest, and the empirical distribution from the control treatment. The latter is clearly skewed towards a higher number of heads than honest behavior predicts. For example, while we should theoretically expect around 0.1 percent of the participants to win the maximum amount, almost 13 percent of the prisoners reported so $(p<0.001$, Binomial test). The distribution from the criminal identity treatment is even further shifted towards higher payoffs (see panel B). The outcome 10, but also the outcomes of 8,7 and 6 times heads were significantly more frequent than honest reporting would predict ( $p<0.001,0.007,0.059$, and 0.097, Binomial tests).

As a result, the average percentage of heads increased significantly from 60 percent in the control group to 66 percent in the criminal identity group ( $p=0.017$, rank-sum test), as shown in panel C. ${ }^{16}$ The corresponding rates of misreported coin flips are 20 percent, and 32 percent respectively, suggesting that cheating is 60 percent more frequent in the criminal identity than in the control treatment. Interestingly, most of the treatment effect comes from incomplete cheaters (i.e., those who report 6,7 and 8 times heads), arguably those who face a stronger tension between their moral and criminal identity.

\footnotetext{
${ }^{15}$ The confidence interval is based on individual averages to account for the fact that reporting behavior could be correlated within individuals.

${ }^{16}$ All p-values reported in this paper are based on two-sided tests except for the Binomial tests which are based on directed hypotheses.
} 
Figure 1: Criminal identity and cheating in inmates
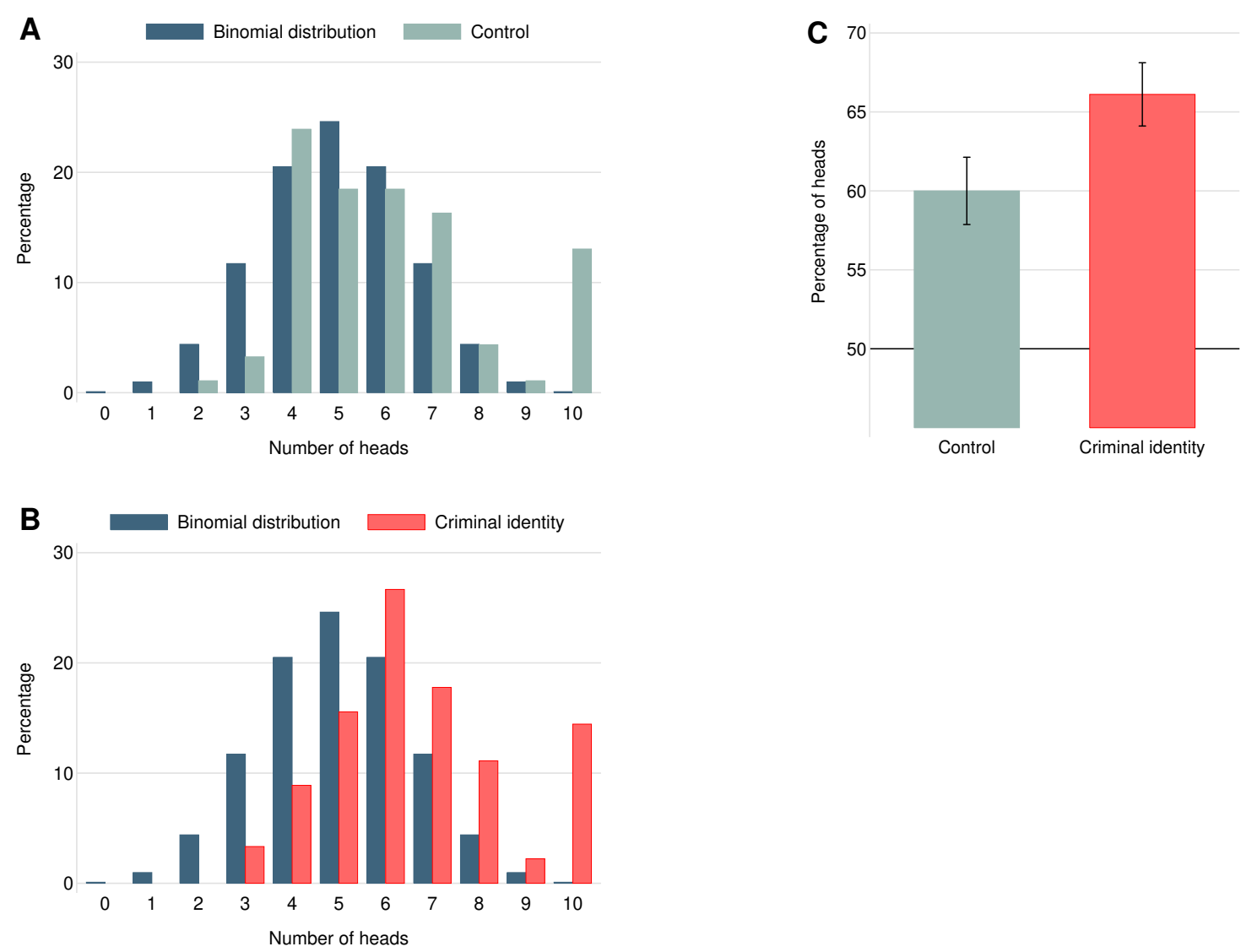

Panel A of this figure shows the distribution of heads reported by the prisoners in the control treatment and the binomial distribution honest reporting implies. Panel B depicts the distribution of heads in the criminal identity treatment and the binomial distribution. Panel $\mathrm{C}$ compares the average percentage of heads reported in the control and in the criminal identity treatments.

The regression results shown in Table 1 are in line with the preceding nonparametric analysis. We estimate a Probit model of the following form:

$$
\operatorname{Pr}\left(h_{e a d} s_{i k}=1\right)=\Phi\left(\alpha+\beta * C_{i}+\gamma * \mathbf{X}_{i}+\epsilon_{i k}\right) .
$$

The decision of individual $i$ to report heads for coin toss $k$ is regressed on the criminal identity treatment dummy $C_{i}$. We additionally control for the residual category of convictions, the number of years in prison, and compulsory schooling level in the vector $\mathbf{X}_{i}$, because these variables were imperfectly balanced across treatments. $\epsilon_{i k}$ is the idiosyncratic error term (standard errors are adjusted for clustering at the individual level). $\Phi(\cdot)$ is the cumulative distribution function of the standard normal distribution. 
Table 1: Regression analysis: Criminal identity and cheating

\begin{tabular}{lccr}
\hline & $(1)$ & $(2)$ & $(3)$ \\
Dependent variable: & & heads $=1$ & \\
\hline Criminal identity & $0.061^{* *}$ & $0.069^{* *}$ & $0.071^{* *}$ \\
& $(0.029)$ & $(0.031)$ & $(0.031)$ \\
Arousal & & -0.011 \\
& & & $(0.007)$ \\
Negative emotions & & & 0.012 \\
& & & $(0.007)$ \\
Risk attitudes & no & yes & $(0.000)$ \\
Additional controls: & 1820 & 1730 & yes \\
\hline Observations & 182 & 173 & 1630 \\
Subjects & & & 163 \\
\hline
\end{tabular}

This table reports average marginal effects from a probit model. Robust standard errors, corrected for clustering on the individual level, are displayed in parentheses. In column (1), the decision to report heads is regressed on the criminal identity treatment dummy. Column (2) additionally controls for the residual category of convictions, the number of years in prison, and compulsory schooling level, because these variables were imperfectly balanced across treatments. Column (3) also controls for arousal, negative emotions, and risk attitudes. Due to item non-response, the number of observations drops when adding covariates. Significance levels: ${ }^{*} \mathrm{p}<0.10,{ }^{* *} \mathrm{p}<0.05,{ }^{* * *} \mathrm{p}<0.01$.

The average treatment effect reported in column (1) of Table 1 reveals that the probability of reporting heads in the criminal identity treatment is 6.1 percentage points higher than in the control condition $(p=0.035)$. As shown in column $(2)$, the estimate of the treatment effect is even slightly larger when we include the additional background characteristics as control variables $(p=0.026) .{ }^{17}$ These findings are summarized in the following result:

Result 1: Prisoners cheat more when their criminal identity is made more salient.

We tested the relevance of alternative interpretations. First, being reminded of one's criminal activity or the social injustice of being incarcerated (Sherman 1993) might have provoked arousal and negative emotions which may have affected dishonesty. We measured participants' arousal and affective state immediately after the priming questions using validated non-verbal Self-Assessment Manikins (Bradley and Lang 1994). However, the results show that the saliency of criminal identity neither had an effect on

\footnotetext{
${ }^{17} \mathrm{We}$ alternatively estimated a linear probability model using ordinary least squares (OLS) which yielded the same results.
} 
arousal ( $p=0.237$, rank-sum test) nor on negative affect ( $p=0.280$, rank-sum test).

Second, the criminal identity manipulation might have altered criminals' risk attitudes (see Benjamin et al. 2010), and thus possibly also their inclination to cheat. Even though it was impossible to detect whether an individual participant cheated, one could argue that some participants erroneously believed that they might get caught and that this would entail negative consequences for them. We elicited inmates' risk attitudes prior to the priming using an experimentally validated questionnaire measure of risk attitudes (Dohmen et al. 2011). We found no significant relationship between individual risk attitudes and behavior in the coin tossing task (Spearman's $\rho=-0.017, p=0.820$ ).

Furthermore, we re-estimated model (7) and controlled for arousal, negative affect, and risk attitudes. Column (3) of Table 1 shows that none of these variables reaches statistical significance and the coefficient estimate for the criminal identity treatment remains unchanged $(p=0.024)$. Together, these results suggest that neither emotions nor risk attitudes are able to explain the treatment effect.

Third, it could be that the prisoners were not completely honest when we asked them about their offenses in order to appear less of a bad person. This could have spilled over to the coin tossing task and undermined honest reporting. For example, it may be easier to rationalize dishonest behavior if one had just lied. If that were the case, it would not be the saliency of criminal identity, but a form of moral disengagement that increased cheating in the criminal identity condition. To test this conjecture, we examined how many prisoners misreported their convictions in the questionnaire (by comparing self-reports to administrative records). Only 7 percent of the prisoners' answers are inconsistent, and an additional 5 percent of prisoners failed to answer the question. We re-estimated our main regression model (7) and restricted the sample to inmates who reported their convictions truthfully. If misreporting in the criminal identity questionnaire induced dishonesty in the subsequent coin tossing task we should observe a weaker or no priming effect in the restricted sample. However, the regression results in Table 2 show that the treatment effect remains virtually the same when we exclude inmates who did not provide truthful responses (columns 1 and 2), or additionally also exclude inmates who did not answer the question (columns 3 and 4). ${ }^{18}$

\footnotetext{
${ }^{18}$ More generally, one could also think of our result as a self-consistency effect, i.e., prisoners may want to behave consistently with their recollection of their previous crimes. Such a self-consistency effect is closely related to the concept of identity because individuals often define themselves through their past behavior (Bem 1972). Hence, reminding prisoners of their criminal past should make their criminal identity more salient. The idea that individuals consider their past behavior to infer their identity is also shared by the recent economic literature on identity. For example, Bénabou and Tirole (2011a) propose a model where individuals only imperfectly recall their sense of identity and use past behavior as a signal for who they are. In a field experiment, Kessler and Milkman (2014) show that reminding charitable donors of their past donations increases current giving, and that the effect is more
} 
Table 2: Robustness checks: Consistency

\begin{tabular}{|c|c|c|c|c|}
\hline Dependent variable: & \multicolumn{3}{|c|}{ heads $=1$} & $(4)$ \\
\hline Criminal identity & $\begin{array}{c}0.062^{* *} \\
(0.030)\end{array}$ & $\begin{array}{c}0.072^{* *} \\
(0.032)\end{array}$ & $\begin{array}{c}0.063^{* *} \\
(0.031)\end{array}$ & $\begin{array}{c}0.076^{* *} \\
(0.033)\end{array}$ \\
\hline Additional controls: & no & yes & no & yes \\
\hline $\begin{array}{l}\text { Observations } \\
\text { Subjects }\end{array}$ & $\begin{array}{r}1690 \\
169\end{array}$ & $\begin{array}{r}1600 \\
160\end{array}$ & $\begin{array}{r}1600 \\
160\end{array}$ & $\begin{array}{r}1510 \\
151\end{array}$ \\
\hline Sample: conviction is... & \multicolumn{3}{|c|}{ truthful or not reported } & thful \\
\hline
\end{tabular}

This table reports average marginal effects from a probit model. Robust standard errors, corrected for clustering on the individual level, are displayed in parentheses. The decision to report heads is regressed on the criminal identity treatment dummy. In column (1) and (2) the sample is restricted to inmates providing truthful (i.e., consistent with administrative records) or no information concerning their conviction. In columns (3) and (4) we additionally excluded inmates who did not provide information concerning their conviction from the sample. The additional controls in column (2) and (4) are the residual category of convictions, the number of years in prison, and compulsory schooling level, because these variables were imperfectly balanced across treatments. Due to item non-response, the number of observations drops when adding covariates. Significance levels: ${ }^{*} \mathrm{p}<0.10,{ }^{* *} \mathrm{p}<0.05,{ }^{* * *} \mathrm{p}<0.01$.

\section{Validity of the Coin Tossing Task}

We present complementary evidence showing that the coin tossing task provides a valid measure of rule violating behavior. We were given access to the anonymized administrative records of disciplinary offenses for each participant. Typical offenses are aggression against others, drug or weapon possession, and other kinds of illegal activities. The average inmate had a record of two disciplinary offenses since the beginning of incarceration. We used this information to test whether behavior in the coin tossing task correlates with inmates' institutional behavior and estimated the following model using OLS:

$$
y_{i}=\alpha+\beta * H_{i}+\gamma * T_{i}+\delta * \mathbf{X}_{i}+\epsilon_{i}
$$

We regressed the number of offenses $y_{i}$ committed by inmate $i$ since incarceration on the percentage of reported heads $H_{i}$ in the coin tossing task. We control for the different windows of opportunity using the time each criminal spent in prison $T_{i}$ as an additional explanatory variable. We further estimated a model, where we control for a large set of additional criminal background measures $\mathbf{X}_{i} . \epsilon_{i}$ is the idiosyncratic error term. Column (1) of Table 3 shows that, on average, inmates who reported ten times heads committed

pronounced for individuals who donate on a regular basis. We thank an anonymous referee for pointing this out. 
two more offenses in prison than those who reported heads in 50 percent of the cases $(p=0.034)$. This difference corresponds to roughly five additional years of imprisonment (see coefficient estimate for "Years in prison"). The regression results are robust even when we control for criminal background and socio-economic characteristics, as shown in columns (2) and (3). ${ }^{19}$ The following result summarizes these findings:

Result 2: Behavior in the coin tossing experiment correlates with rule violating behavior in prison.

Table 3: Prison rule violations and behavior in the coin tossing task

\begin{tabular}{|c|c|c|c|}
\hline & (1) & $(2)$ & $(3)$ \\
\hline Dependent variable: & \multicolumn{3}{|c|}{ \# of disciplinary offenses } \\
\hline Percentage of heads & $\begin{array}{c}0.040^{* *} \\
(0.019)\end{array}$ & $\begin{array}{c}0.037^{* *} \\
(0.018)\end{array}$ & $\begin{array}{c}0.037^{* *} \\
(0.018)\end{array}$ \\
\hline Years in prison & $\begin{array}{c}0.404^{* * *} \\
(0.109)\end{array}$ & $\begin{array}{c}0.279^{* *} \\
(0.109)\end{array}$ & $\begin{array}{c}0.433^{* * *} \\
(0.140)\end{array}$ \\
\hline $\begin{array}{l}\text { Criminal background } \\
\text { Type of conviction } \\
\text { Repeat offender } \\
\text { Prison section }\end{array}$ & $\begin{array}{l}\text { no } \\
\text { no } \\
\text { no }\end{array}$ & $\begin{array}{l}\text { yes } \\
\text { yes } \\
\text { yes }\end{array}$ & $\begin{array}{l}\text { yes } \\
\text { yes } \\
\text { yes }\end{array}$ \\
\hline $\begin{array}{l}\text { Socio-economic control } \\
\text { Age } \\
\text { Nationality } \\
\text { Education }\end{array}$ & $\begin{array}{l}\text { no } \\
\text { no } \\
\text { no }\end{array}$ & $\begin{array}{l}\text { no } \\
\text { no } \\
\text { no }\end{array}$ & $\begin{array}{l}\text { yes } \\
\text { yes } \\
\text { yes }\end{array}$ \\
\hline Observations & 182 & 182 & 159 \\
\hline
\end{tabular}

This table reports OLS coefficient estimates. Robust standard errors are displayed in parentheses. In column (1), the number of disciplinary offenses is regressed on the percentage of heads reported and the number of years in prison. Column (2) includes additional criminal background controls, such as type of conviction, repeat offender status, and prison section. We do not control for sentence length because it is not determined for more than one-third of the sample (early imprisonment and safe custody). Column (3) also controls for age, nationality, and education. Significance levels: ${ }^{*} \mathrm{p}<0.10,{ }^{* *} \mathrm{p}<0.05,{ }^{* * *} \mathrm{p}$ $<0.01$.

\section{Manipulation Check}

Six months after the main study we conducted a second experiment with 119 inmates from the same prison using the same procedure. The goal of this follow-up experiment

\footnotetext{
${ }^{19} \mathrm{We}$ alternatively treated disciplinary offenses as count data and estimated a negative binomial regression model which yielded similar results.
} 
was to measure the impact of the priming questions on criminal cognition, which serves as a manipulation check.

The first part of the follow-up survey included new filler questions, mostly on subjective wellbeing (see online appendix). The second part contained exactly the same six priming questions as in the previous experiment. ${ }^{20}$ Following the six priming questions, participants solved a word stem completion task. For example, they could complete the word stem "off..." with the crime-related word "offense" or unrelated words such as "office". The other two word stems were "acc..." (e.g., accusation vs. account) and "pol..." (e.g., police vs. politics). A research assistant who was blind to the experimental conditions categorized the answers into crime-related and unrelated words. This allows us to compare the mental accessibility of crime-related constructs across treatments.

As depicted in Figure 2, the mental accessibility of crime-related constructs was effectively manipulated. In comparison to the control condition, the participants in the criminal identity treatment mentioned crime-related words almost twice as frequently $(p=0.008$, rank-sum test).

Result 3: In comparison with the control treatment, the criminal identity treatment increased the mental saliency of crime-related constructs, suggesting that the treatment manipulation worked as intended.

\section{Placebo Experiment with Regular Citizens}

We conducted an additional placebo experiment with subjects from the general population in order to further consolidate our results with an effect of criminal identification. An alternative explanation for the previous findings is that not the salience of criminal identity per se, but rather crime-related thoughts in general, increased cheating. It is conceivable that exposure to crime-related content evoked semantically related thoughts and thereby lowered moral standards. This alternative mechanism would imply that regular citizens react similarly to crime-related priming questions. In contrast, our identity framework predicts that non-criminal subjects will not react to crime-related cues

\footnotetext{
${ }^{20} 69$ inmates had already participated in the first experiment; the other 50 inmates participated for the first time. Table A2 in the appendix shows the descriptive statistics of the participants of the manipulation check. The randomization check in the last column suggests that all background characteristics are well balanced across treatments. Treatments were randomly assigned for subjects who participated for the first time. We reversed treatment assignment for subjects who already participated in the main experiment: those who originally answered the criminal identity questions received the control questions instead, and vice versa. Seven subjects received the same treatment in the main experiment and the manipulation check by mistake. The results are robust to excluding these subjects.
} 
Figure 2: Manipulation check

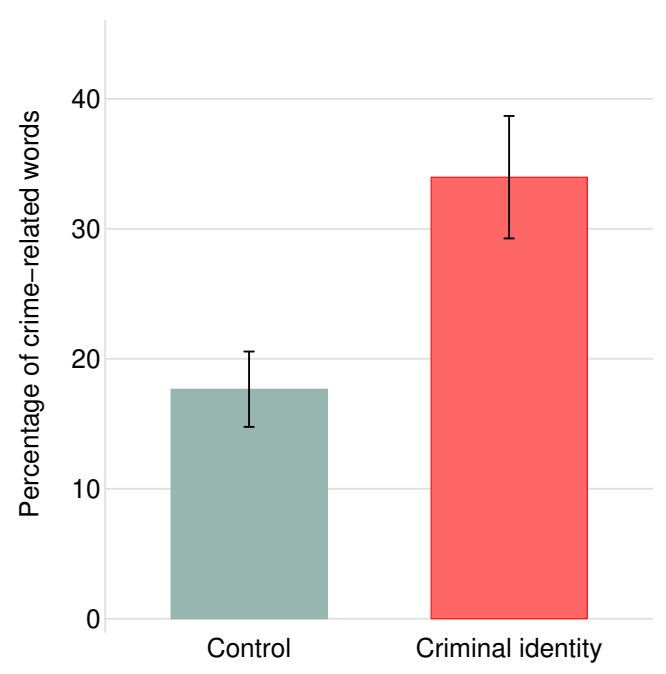

This figure shows the average percentage of crime-related words in the word completion task by treatment.

because they do not have a criminal identity that can be made more salient (i.e., $\bar{s}=0$ and therefore $s=\bar{s} \cdot \epsilon=0){ }^{21}$

To test this prediction, we recruited 193 male visitors from the resident registration office of a Swiss municipality. ${ }^{22}$ We deliberately chose a municipality characterized by a relatively high proportion of foreigners in order to recruit participants with a similar cultural background to that of the prisoners. Moreover, recruitment at the registration office allowed us to approach representative citizens of the chosen community. ${ }^{23}$ The experimental design and procedure followed the prisoners' experiment as closely as possible. Participants were assured that their answers would be treated confidentially, and they could choose their preferred survey language among the same four options. Subjects received an envelope that contained the survey, and a second smaller envelope with ten 0.5 Swiss franc coins. Participants filled out the survey alone in an empty room at the resident registration office, ensuring the same degree of privacy during the experiment. They received an additional fixed show up fee of 10 Swiss francs in order to compensate

\footnotetext{
${ }^{21}$ See LeBoeuf et al. (2010) for evidence that identity priming only affects behavior if subjects have the primed identity.

${ }^{22}$ We cannot rule out that some of our subjects might have committed crimes because we do not know their criminal histories. However, if some of the subjects were indeed criminals, their presence would work against our prediction, making the test even stronger.

${ }^{23}$ Citizens mostly visit the registration office to receive or renew official documents, such as passports and residency permits.
} 
them for their higher opportunity costs of time. The survey was identical to that administered to the prisoners, except for the treatment manipulation, which needed to be adjusted slightly. Before answering the crime or control questions, participants had to memorize a short text profile of a person. They were randomly assigned to a profile of a criminal or a non-criminal person. We created these profiles using representative answers from the prisoners in the criminal identity and the control treatment, respectively (see online appendix). Subjects subsequently answered the same six priming questions as the prisoners but from the perspective of the person described in the profile. After the quiz, participants were asked to open the second envelope and to complete the coin tossing task. At the end of the experiment, participants returned the sealed envelopes by putting them into a box placed in the corner of the room. Table A3 in the appendix presents descriptive statistics and the randomization check for the placebo experiment. There are no significant differences between treatments for any of the elicited background characteristics, with the exception of vocation $\operatorname{schooling}\left(p=0.043, \chi^{2}\right.$ test $)$, suggesting that the randomization was successful.

The results show that the general population reported, on average, 56 percent of heads in the coin tossing task (95\% confidence interval: 53\%, 59\%). This corresponds to 12 percent misreporting. Thus, participants from the general population cheated too, but to a lesser extent than the criminals ( $p=0.004$, rank-sum test). A clear difference between the sample of criminals and the non-criminal population is the occurrence of the payoff maximizing outcome. While the criminals in the control treatment reported ten times heads in 13 percent of cases, the same outcome is observed only in 4 percent of cases in the control group of the non-criminal population $\left(p=0.031, \chi^{2}\right.$ test). However, these differences should be interpreted cautiously, because they could also be attributed to unobserved factors which differ between the two social groups. The relevant question is whether the treatment influenced cheating within the general population.

Panel A of Figure 3 contrasts the binomial distribution of heads with the empirical distribution observed in the control group of the general population. The distribution is shifted to the right, suggesting that individuals over-reported the number of heads. In contrast to the experiment with the prisoners, the distribution from the criminal profile treatment is very similar to that in the control treatment, as shown in panel B. Panel $\mathrm{C}$ highlights that the average percentage of heads is even slightly lower in the criminal profile (55 percent heads or 10 percent misreporting) compared to the control treatment (57 percent of heads or 14 percent misreporting), but not significantly so ( $\mathrm{p}=0.240$, rank-sum test). Thus, if anything, the general population tended to cheat less when primed with the criminal profile rather than the control profile. Overall, the results from 
Figure 3: Crime-related reminders and cheating in regular citizens
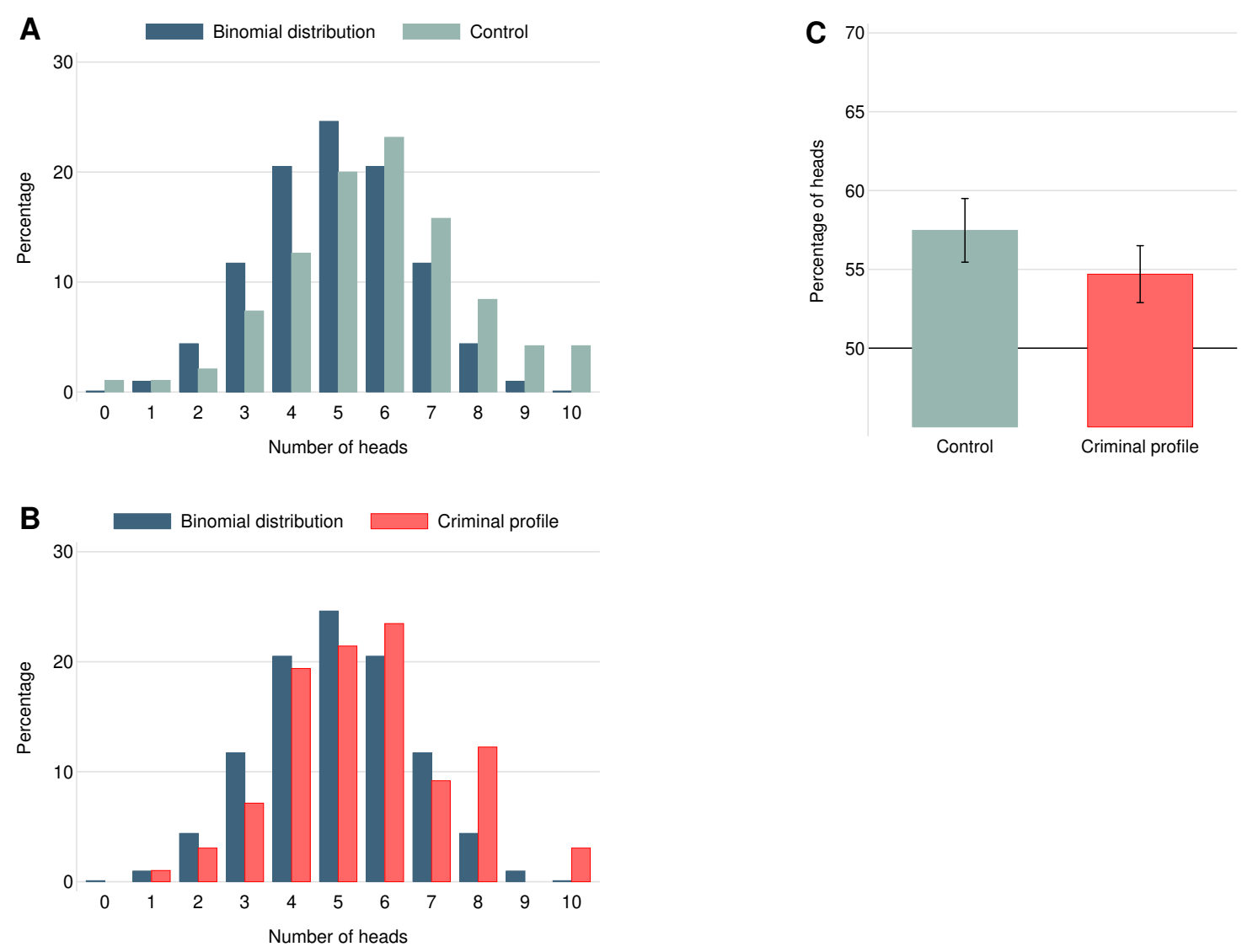

Panel A of this figure shows the distribution of heads reported by the non-criminal population in the control treatment and the binomial distribution implied by honest reporting. Panel B depicts the distribution of heads in the criminal identity treatment and the binomial distribution. Panel C compares the average percentage of heads reported in the control and criminal identity treatment.

the placebo experiment suggest that the priming effect is specific to criminals and is thus consistent with a criminal identity effect. This is summarized in the final result:

Result 4: Regular citizens do not cheat more when crime-related concepts are rendered more salient.

Note that this result is consistent with the self-concept maintenance theory proposed by Mazar et al. (2008). According to their framework, a moral prime renders non-criminal subjects more honest because it reminds them of their own moral standards. Our prime, however, was based on the immoral behavior of a third person. One could even argue that when subjects are asked to think about the crimes of another person, their moral self-image is threatened and they therefore engage in counteractive behavior (see Zhong 
and Liljenquist 2006). This might explain why subjects in the criminal profile condition tended to be more honest than those in the control condition.

\section{Conclusion}

We study the impact of criminal identity salience on rule violating behavior in 182 inmates from a maximum security prison. We experimentally manipulated the saliency of their criminal identity and subsequently measured their dishonesty in an incentivized coin tossing task. Our results show that prisoners cheated substantially more when their criminal identity was rendered more salient. This effect is specific to individuals with a criminal identity, as we did not find any influence of crime-related reminders in a placebo experiment with regular citizens. Furthermore, we show that our experimental measure of dishonesty correlates with inmates' disciplinary offenses. Together, these findings suggest that criminal identity salience plays a crucial role in rule violating behavior and also support recent theoretical endeavors incorporating identity into economic models of decision making (e.g., Akerlof and Kranton 2000, Fang and Loury 2005, and Bénabou and Tirole 2011a).

It may seem surprising that we were able to increase the saliency of criminal identity of maximum security prisoners given that they are locked in an environment which constantly reminds them of their criminal identities. However, our results from both the coin tossing task and the manipulation check suggest that everyday prison life does not necessarily render inmates' criminal identities maximally salient at all times. Inmates are probably able to distract themselves and therefore habituate to the permanent cues in their environment.

From a policy perspective, our results raise the possibility that legal sanctions can have side effects with unintended consequences. Convictions often come along with collateral consequences, such as deprivations of civil rights, loss of professional licenses, or restricted access to public benefits (Travis 2002). The intended deterrent effects of these consequences may come at the cost of reminding convicts of their criminal identity, which may increase their risk for relapse. As discussed above, however, permanent reminders are potentially less problematic than intermittent or novel cues. Identifying the extent to which the saliency of criminal identity counteracts the deterrent effects of collateral consequences is therefore an important avenue for future research. 


\section{References}

Abeler, Johannes, Anke Becker, and Armin Falk (2014): "Representative Evidence on Lying Costs", Journal of Public Economics, Vol. 113, pp. 96-104.

Acemoglu, Daron and Matthew O. Jackson (2014): "Social Norms and the Enforcement of Laws", NBER Working Paper No. 20369.

Akerlof, George A. and Rachel E. Kranton (2000): "Economics and Identity", Quarterly Journal of Economics, Vol. 115, No. 3, pp. 715-753.

Alesina, Alberto, Paola Giuliano, and Nathan Nunn (2013): "On the Origins of Gender Roles: Women and the Plough", Quarterly Journal of Economics, Vol. 128, No. 2, pp. 469-530.

Anderson, David A (1999): The Aggregate Burden of Crime, Journal of Law and Economics, Vol. 42, No. 2, pp. 611-642.

Anderson, Elijah (2000): Code of the Street: Decency, Violence, and the Moral Life of the Inner City, New York: W.W. Norton \& Company.

Ariely, Dan (2012): The (Honest) Truth about Dishonesty: How we Lie to Everyone Especially Ourselves, New York: HarperCollins.

Balafoutas, Loukas, Adrian Beck, Rudolf Kerschbamer, and Matthias Sutter (2013): "What Drives Taxi Drivers? A Field Experiment on Fraud in a Market for Credence Goods", Review of Economic Studies, Vol. 80, No. 3, pp. 876-891.

Bargh, John A. and Tanya L. Chartrand (2000): "The Mind in the Middle: A Practical Guide to Priming and Automaticity Research", in: H. T. Reis and C. M. Judd (Eds.), Handbook of Research Methods in Social Psychology, pp. 253-285, New York: Cambridge University Press.

Becker, Gary S. (1968): "Crime and Punishment: An Economic Approach", Journal of Political Economy, Vol. 76, No. 2, pp. 169-217.

Becker, S., Howard (1963): Outsiders: Studie in the Sociology of Deviance, New York: The Free Press.

Bem, J., Daryl (1972): "Self-Perception Theory", in: Leonard Berkowitz (Ed.), Advances in Experimental Social Psychology, Vol. 6, pp. 1-62, New York: Academic Press.

Bénabou, Roland and Jean Tirole (2011a): "Identity, Morals, and Taboos: Beliefs as Assets", Quarterly Journal of Economics, Vol. 126, No. 2, pp. 805-855.

Bénabou, Roland and Jean Tirole (2011b): "Laws and Norms", NBER Working Paper No 15579.

Benjamin, Daniel J., James J. Choi, and Geoffrey Fisher (2013): "Religious Identity and Economic Behavior", Working paper. 
Benjamin, Daniel J., James J. Choi, and Joshua A. Strickland (2010): "Social Identity and Preferences", American Economic Review, Vol. 100, No. 4, pp. 1913-1928.

Bertrand, Marianne, Emir Kamenica, and Jessica Pan (2013): "Gender Identitiy and Relative Income within Housholds", Working paper.

Birkeland, Sigbjørn, Alexander W. Cappelen, Erik Ø. Sørensen, and Bertil Tungodden (forthcoming): "An Experimental Study of Prosocial Motivation Among Criminals", Experimental Economics.

Bradley, Margaret M. and Peter J. Lang (1994): "Measuring emotion: the self-assessment manikin and the semantic differential", Journal of Behavior Therapy and Experimental Psychiatry, Vol. 25, No. 1, pp. 49-59.

Bradley, Margaret M. and Peter J. Lang (2000): "Measuring Emotion: Behavior, Feeling, and Physiology", in: Richard Lane, Lynn Nadel, and Geoffrey Ahern (Eds.), Cognitive Neuroscience of Emotion, pp. 242-276, Oxford University Press.

Callen, Michael, Mohammad Isaqzadeh, James D. Long, and Charles Sprenger (forthcoming): "Violent Trauma and Risk Preference: Experimental Evidence from Afghanistan", Quarterly Journal of Economics.

Chalfin, Aaron and Justin McCrary (2014): "Criminal Deterrence: A Review of the Literature", Working paper.

Charness, Gary and Martin Dufwenberg (2006): "Promises and Partnership", Econometrica, Vol. 74, No. 6, pp. 1579-1601.

Charness, Gary, Luca Rigotti, and Aldo Rustichini (2007): "Individual Behavior and Group Membership", American Economic Review, Vol. 97, No. 4, pp. 1340-1352.

Chen, Yan and Sherry X. Li (2009): "Group Identity and Social Preferences", American Economic Review, Vol. 99, No. 1, pp. 431-457.

Chen, Yan, Sherry X. Li, Tracy X. Liu, and Margaret Shih (2010): "Which Hat to Wear? Impact of Natural Identities on Coordination and Cooperation", Working paper.

Chmura, Thorsten, Christoph Engel, and Markus Englerth (2013): "Selfishness As a Potential Cause of Crime. A Prison Experiment", Working paper.

Cohen, Albert K. (1955): Delinquent Boys: The Culture Of The Gang, New York: The Free Press.

Cohn, Alain, Ernst Fehr, and Michel A. Maréchal (2014): "Business Culture and Dishonesty in the Banking Industry", Nature, Vol. 516, pp. 86-89.

Dohmen, Thomas, Armin Falk, David Huffman, Uwe Sunde, Jürgen Schupp, and Gert G. Wagner (2011): "Individual Risk Attitudes: Measurement, Determinants, and Behavioral Consequences", Journal of the European Economic Association, Vol. 9, No. 3, pp. $522-550$. 
Draca, Mirco and Stephen Machin (2015): "Crime and Economic Incentives", Working paper.

Ellingsen, Tore and Magnus Johannesson (2004): "Promises, Threats and Fairness", Economic Journal, Vol. 114, No. 495, pp. 397-420.

Fang, Hanming and Glenn C. Loury (2005): "Dysfunctional Identities Can Be Rational", American Economic Review, Vol. 95, No. 2, pp. 104-111.

Fischbacher, Urs and Franziska Föllmi-Heusi (2013): "Lies in Disguise - An Experimental Study on Cheating", Journal of the European Economic Association, Vol. 11, No. 3, pp. 525-547.

Frederick, Shane (2005): "Cognitive Reflection and Decision Making", Journal of Economic Perspectives, Vol. 19, No. 4, pp. 25-42.

Gendreau, P., T. Little, and C. Goggin (1996): "Meta-Analysis of the Predictors of Adult Offender Recidivism: What Works!", Criminology, Vol. 34, No. 4, pp. 575-607.

Gneezy, Uri (2005): "Deception: The role of consequences", American Economic Review, Vol. 95, No. 1, pp. 384-394.

Goette, Lorenz, David Huffman, and Stephan Meier (2012): "The Impact of Social Ties on Group Interactions: Evidence from Minimal Groups and Randomly Assigned Real Groups", American Economic Journal: Microeconomics, Vol. 4, No. 1, pp. 101-115.

Hoff, Karla and Priyanka Pandey (2006): "Discrimination, Social Identity, and Durable Inequalities", American Economic Review, Vol. 96, No. 2, pp. 206-211.

Hoff, Karla and Priyanka Pandey (forthcoming): "Making Up People - The Effect of Identity on Performance in a Modernizing Society", Journal of Development Economics.

Houser, Daniel, Stefan Vetter, and Joachim Winter (2012): "Fairness and Cheating", European Economic Review, Vol. 56, No. 8, pp. 1645-1655.

Kaplan, Howard B. (1975): Self-attitudes and Deviant Behavior, Oxford: Goodyear.

Kartik, Navin (2009): Strategic Communication with Lying Costs, Review of Economic Studies, Vol. 76, No. 4, pp. 1359-1395.

Kessler, B., Judd and L. Milkman, Katherine (2014): "Identity in Charitable Giving", Working paper.

Khadjavi, Menusch and Andreas Lange (2013): "Prisoners and their Dilemma", Journal of Economic Behavior \&f Organization, Vol. 92, pp. 163-175, ISSN 0167-2681.

Kranton, Rachel E., Matthew Pease, Seth Sanders, and Scott Huettel (2012): "Identity, Group Conflict, and Social Preferences", Working paper. 
LeBoeuf, Robyn A., Eldar Shafir, and Julia Belyavsky Bayuk (2010): "The Conflicting Choices of Alternating Selves", Organizational Behavior and Human Decision Processes, Vol. 111, No. 1, pp. 48-61.

Lerman, Amy E. (2009): "The People Prisons Make: Effects of Incarceration on Criminal Psychology", in: Raphael Steven and Michael Stoll (Eds.), Do Prisons Make Us Safer?: The Benefits and Costs of the Prison Boom, pp. 151-176, New York: Russell Sage Foundation.

Ludwig, Jens (2006): Testimony to the U.S. Senate Judiciary Committee, September 19, 2006, retrieved April 30, 2015 from http: //gpo.gov/fdsys/pkg/CHRG-109shrg42938/html/CHRG-109shrg42938.htm.

Mazar, Nina, On Amir, and Dan Ariely (2008): "The Dishonesty of Honest People: A Theory of Self-Concept Maintenance", Journal of Marketing Research, Vol. 45, No. 6, pp. 633-644.

McAdams, Richard H and Eric B Rasmusen (2007): "Norms and the Law", in: Mitchell A. Polinsky and Steven Shavell (Eds.), Handbook of Law and Economics, Vol. 2, pp. 1573-1618, Elsevier.

Nagin, Daniel S. (2013): "Deterrence: A Review of the Evidence by a Criminologist for Economists", Annual Review of Economics, Vol. 5, No. 1, pp. 83-105.

Pew Center on the States (2011): State of Recidivism: The Revolving Door of America's Prisons, Washington, DC: Pew Charitable Trust.

Posner, Eric A. (2009): Law and Social Norms, Cambridge: Harvard University Press.

Pruckner, Gerald J. and Rupert Sausgruber (2013): "Honesty on the Streets: A Field Study on Newspaper Purchasing", Journal of the European Economic Association, Vol. 11, No. 3, pp. 661-679.

Reckless, Walter Cade (1967): The Crime Problem, New York: Appleton-CenturyCrofts.

Shalvi, Shaul, Jason Dana, Michel J.J. Handgraaf, and Carsten DeDreu (2011): "Justified Ethicality: Observing Desired Counterfactuals Modifies Ethical Perceptions and Behavior", Organizational Behavior and Human Decision Processes, Vol. 115, No. 2, pp. 181-190.

Sherman, Lawrence W. (1993): "Defiance, Deterrence, and Irrelevance: A Theory of the Criminal Sanction", Journal of Research in Crime and Delinquency, Vol. 30, No. 4, pp. $445-473$.

Shih, Margaret, Todd L. Pittinsky, and Nalini Ambady (1999): "Stereotype Susceptibility: Identity Salience and Shifts in Quantitative Performance", Psychological Science, Vol. 10, No. 1, pp. 80-83. 
Simourd, David J. and Mark E. Olver (2002): "The Future of Criminal Attitudes Research and Practice", Criminal Justice and Behavior, Vol. 29, No. 4, pp. 427-446.

Travis, Jeremy (2002): "Invisible Punishment: An Instrument of Social Exclusion", in: Meda Chesney-Lind and Marc Mauer (Eds.), Invisible Punishment: The Collateral Consequences of Mass Imprisonment, New York: The New Press.

Walters, Glenn D. (2003): "Changes in Criminal Thinking and Identity in Novice and Experienced Inmates Prisonization Revisited", Criminal Justice and Behavior, Vol. 30, No. 4, pp. 399-421.

Zhong, Chen-Bo and Katie Liljenquist (2006): "Washing Away Your Sins: Threatened Morality and Physical Cleansing", Science, Vol. 313, No. 5792, pp. 1451-1452. 
Appendix 
Table A1: Descriptive statistics of the main experiment

\begin{tabular}{|c|c|c|c|c|c|c|c|}
\hline \multirow[b]{2}{*}{ Variable } & \multicolumn{2}{|c|}{$\begin{array}{c}\text { Total sample } \\
\mathrm{N}=182\end{array}$} & \multicolumn{2}{|c|}{$\begin{array}{c}\text { Criminal identity } \\
\mathrm{N}=90\end{array}$} & \multicolumn{2}{|c|}{$\begin{array}{c}\text { Control } \\
\mathrm{N}=92\end{array}$} & \multirow[b]{2}{*}{ p-value } \\
\hline & mean & sd & mean & sd & mean & sd & \\
\hline \multicolumn{8}{|l|}{ Type of conviction: } \\
\hline Violent crimes & 0.297 & $(0.458)$ & 0.256 & $(0.439)$ & 0.337 & $(0.475)$ & 0.229 \\
\hline Drug-related crimes & 0.264 & $(0.442)$ & 0.278 & $(0.450)$ & 0.250 & $(0.435)$ & 0.671 \\
\hline Property crimes & 0.242 & $(0.429)$ & 0.267 & $(0.445)$ & 0.217 & $(0.415)$ & 0.438 \\
\hline Sex crimes & 0.148 & $(0.356)$ & 0.189 & $(0.394)$ & 0.109 & $(0.313)$ & 0.128 \\
\hline Other & 0.049 & $(0.217)$ & 0.011 & $(0.105)$ & 0.087 & $(0.283)$ & 0.018 \\
\hline Repeat offender & 0.621 & $(0.487)$ & 0.567 & $(0.498)$ & 0.674 & $(0.471)$ & 0.136 \\
\hline \multicolumn{8}{|l|}{ Sentences: } \\
\hline Sentence length (if known) & 4.574 & $(4.364)$ & 5.082 & $(4.580)$ & 4.065 & $(4.114)$ & 0.167 \\
\hline Safe custody & 0.176 & $(0.382)$ & 0.178 & $(0.384)$ & 0.174 & $(0.381)$ & 0.945 \\
\hline Early imprisonment & 0.176 & $(0.382)$ & 0.167 & $(0.375)$ & 0.185 & $(0.390)$ & 0.748 \\
\hline Years in prison & 2.659 & $(3.922)$ & 3.055 & $(4.433)$ & 2.272 & $(3.326)$ & 0.100 \\
\hline \multicolumn{8}{|l|}{ Prison section: } \\
\hline Double cell & 0.352 & $(0.479)$ & 0.367 & $(0.485)$ & 0.337 & $(0.475)$ & 0.675 \\
\hline Single cell (normal) & 0.368 & $(0.484)$ & 0.356 & $(0.481)$ & 0.380 & $(0.488)$ & 0.728 \\
\hline Single cell (special) & 0.280 & $(0.450)$ & 0.278 & $(0.450)$ & 0.283 & $(0.453)$ & 0.942 \\
\hline No. of disciplinary offenses & 2.187 & $(4.371)$ & 2.533 & $(4.432)$ & 1.848 & $(4.307)$ & 0.131 \\
\hline \multicolumn{8}{|l|}{ Nationality: } \\
\hline Swiss & 0.322 & $(0.468)$ & 0.369 & $(0.485)$ & 0.276 & $(0.450)$ & 0.192 \\
\hline South-eastern European & 0.298 & $(0.459)$ & 0.262 & $(0.442)$ & 0.333 & $(0.474)$ & 0.307 \\
\hline African & 0.146 & $(0.354)$ & 0.143 & $(0.352)$ & 0.149 & $(0.359)$ & 0.903 \\
\hline Central European & 0.123 & $(0.329)$ & 0.107 & $(0.311)$ & 0.138 & $(0.347)$ & 0.540 \\
\hline Other & 0.111 & $(0.315)$ & 0.119 & $(0.326)$ & 0.103 & $(0.306)$ & 0.746 \\
\hline Age & 38.341 & $(11.306)$ & 39.246 & $(12.059)$ & 37.497 & $(10.553)$ & 0.479 \\
\hline \multicolumn{8}{|l|}{ Highest completed education: } \\
\hline Compulsory school & 0.376 & $(0.486)$ & 0.437 & $(0.499)$ & 0.314 & $(0.467)$ & 0.095 \\
\hline Vocational school & 0.347 & $(0.477)$ & 0.345 & $(0.478)$ & 0.349 & $(0.479)$ & 0.956 \\
\hline High school & 0.087 & $(0.282)$ & 0.057 & $(0.234)$ & 0.116 & $(0.322)$ & 0.169 \\
\hline Teaching diploma & 0.023 & $(0.151)$ & 0.011 & $(0.107)$ & 0.035 & $(0.185)$ & 0.306 \\
\hline Adv. vocational school & 0.104 & $(0.306)$ & 0.115 & $(0.321)$ & 0.093 & $(0.292)$ & 0.637 \\
\hline Univ. of applied sciences & 0.035 & $(0.184)$ & 0.023 & $(0.151)$ & 0.047 & $(0.212)$ & 0.398 \\
\hline University & 0.029 & $(0.168)$ & 0.011 & $(0.107)$ & 0.047 & $(0.212)$ & 0.169 \\
\hline Risk attitudes & 5.392 & $(3.036)$ & 5.163 & $(2.854)$ & 5.626 & $(3.212)$ & 0.294 \\
\hline Cognitive skills & 0.676 & $(0.974)$ & 0.778 & $(1.036)$ & 0.576 & $(0.905)$ & 0.152 \\
\hline \multicolumn{8}{|l|}{ Survey language: } \\
\hline German & 0.709 & $(0.456)$ & 0.722 & $(0.450)$ & 0.696 & $(0.463)$ & 0.693 \\
\hline English & 0.126 & $(0.333)$ & 0.111 & $(0.316)$ & 0.141 & $(0.350)$ & 0.540 \\
\hline Italian & 0.099 & $(0.299)$ & 0.089 & $(0.286)$ & 0.109 & $(0.313)$ & 0.655 \\
\hline French & 0.066 & $(0.249)$ & 0.078 & $(0.269)$ & 0.054 & $(0.228)$ & 0.524 \\
\hline
\end{tabular}

All variables are binary, except for sentence length (in years), years in prison, number of disciplinary offenses, age (in years), risk attitudes (from 0 "not at all willing to take risks" to 10 "fully willing to take risks"), and cognitive skills (score in the cognitive reflection test ranging from 0 to 3). "Single cell (normal)" and "Single cell (special)" means single cell in normal, respectively special correction facility. Sentence length is known for 118 subjects. Due to item non-response, 11 observations are missing for nationality, 8 for age, 9 for education, and 6 for risk attitudes. The last column presents p-values for the null hypothesis of perfect randomization $\left(\chi^{2}\right.$ tests in case of binary variables and rank-sum tests in case of interval variables). 
Table A2: Descriptive statistics of the manipulation check

\begin{tabular}{|c|c|c|c|c|c|c|c|}
\hline \multirow[b]{2}{*}{ Variable } & \multicolumn{2}{|c|}{$\begin{array}{c}\text { Total sample } \\
\mathrm{N}=119\end{array}$} & \multicolumn{2}{|c|}{$\begin{array}{c}\text { Criminal identity } \\
\mathrm{N}=52\end{array}$} & \multicolumn{2}{|c|}{$\begin{array}{c}\text { Control } \\
\mathrm{N}=67\end{array}$} & \multirow[b]{2}{*}{ p-value } \\
\hline & mean & sd & mean & sd & mean & sd & \\
\hline \multicolumn{8}{|l|}{ Type of conviction: } \\
\hline Violent crimes & 0.319 & $(0.468)$ & 0.346 & $(0.480)$ & 0.299 & $(0.461)$ & 0.580 \\
\hline Drug-related crimes & 0.269 & $(0.445)$ & 0.327 & $(0.474)$ & 0.224 & $(0.420)$ & 0.209 \\
\hline Property crimes & 0.218 & $(0.415)$ & 0.192 & $(0.398)$ & 0.239 & $(0.430)$ & 0.543 \\
\hline Sex crimes & 0.151 & $(0.360)$ & 0.096 & $(0.298)$ & 0.194 & $(0.398)$ & 0.139 \\
\hline Other & 0.042 & $(0.201)$ & 0.038 & $(0.194)$ & 0.045 & $(0.208)$ & 0.865 \\
\hline Repeat offender & 0.538 & $(0.501)$ & 0.519 & $(0.505)$ & 0.552 & $(0.501)$ & 0.720 \\
\hline \multicolumn{8}{|l|}{ Sentences: } \\
\hline Sentence length (if known) & 5.649 & $(4.260)$ & 4.674 & $(3.295)$ & 6.327 & $(4.746)$ & 0.131 \\
\hline Safe custody & 0.218 & $(0.415)$ & 0.250 & $(0.437)$ & 0.194 & $(0.398)$ & 0.464 \\
\hline Early imprisonment & 0.269 & $(0.445)$ & 0.269 & $(0.448)$ & 0.269 & $(0.447)$ & 0.994 \\
\hline Years in prison & 2.522 & $(4.005)$ & 2.246 & $(3.787)$ & 2.736 & $(4.181)$ & 0.183 \\
\hline \multicolumn{8}{|l|}{ Prison section: } \\
\hline Double cell & 0.303 & $(0.461)$ & 0.308 & $(0.466)$ & 0.299 & $(0.461)$ & 0.914 \\
\hline Single cell (normal) & 0.319 & $(0.468)$ & 0.250 & $(0.437)$ & 0.373 & $(0.487)$ & 0.153 \\
\hline Single cell (special) & 0.378 & $(0.487)$ & 0.442 & $(0.502)$ & 0.328 & $(0.473)$ & 0.204 \\
\hline No. of disciplinary offenses & 2.571 & (5.148) & 2.442 & $(5.707)$ & 2.672 & $(4.711)$ & 0.226 \\
\hline \multicolumn{8}{|l|}{ Survey language: } \\
\hline German & 0.840 & $(0.368)$ & 0.808 & $(0.398)$ & 0.866 & $(0.344)$ & 0.392 \\
\hline English & 0.084 & $(0.279)$ & 0.096 & $(0.298)$ & 0.075 & $(0.265)$ & 0.675 \\
\hline Italian & 0.050 & $(0.220)$ & 0.077 & $(0.269)$ & 0.030 & $(0.171)$ & 0.244 \\
\hline French & 0.025 & $(0.157)$ & 0.019 & $(0.139)$ & 0.030 & $(0.171)$ & 0.714 \\
\hline
\end{tabular}

All variables are binary, except for sentence length (in years), years in prison, and number of disciplinary offenses. "Single cell (normal)" and "Single cell (special)" means single cell in normal, respectively special correction facility. Sentence length is known for 61 subjects. The last column presents p-values for the null hypothesis of perfect randomization $\left(\chi^{2}\right.$ tests in case of binary variables and rank-sum tests in case of interval variables). 
Table A3: Descriptive statistics of the placebo experiment

\begin{tabular}{|c|c|c|c|c|c|c|c|}
\hline \multirow[b]{2}{*}{ Variable } & \multicolumn{2}{|c|}{$\begin{array}{c}\text { Total sample } \\
\mathrm{N}=193\end{array}$} & \multicolumn{2}{|c|}{$\begin{array}{c}\text { Criminal profile } \\
N=98\end{array}$} & \multicolumn{2}{|c|}{$\begin{array}{l}\text { Control } \\
\mathrm{N}=95\end{array}$} & \multirow[b]{2}{*}{ p-value } \\
\hline & mean & sd & mean & sd & mean & sd & \\
\hline \multicolumn{8}{|l|}{ Nationality: } \\
\hline Swiss & 0.587 & $(0.494)$ & 0.573 & $(0.497)$ & 0.602 & $(0.492)$ & 0.683 \\
\hline South-eastern European & 0.106 & $(0.308)$ & 0.083 & $(0.278)$ & 0.129 & $(0.337)$ & 0.307 \\
\hline African & 0.011 & $(0.103)$ & 0.010 & $(0.102)$ & 0.011 & $(0.104)$ & 0.982 \\
\hline Central European & 0.243 & $(0.430)$ & 0.271 & $(0.447)$ & 0.215 & $(0.413)$ & 0.372 \\
\hline Other & 0.053 & $(0.224)$ & 0.063 & $(0.243)$ & 0.043 & $(0.204)$ & 0.550 \\
\hline Age & 41.605 & $(17.155)$ & 42.930 & $(18.236)$ & 40.251 & $(15.963)$ & 0.424 \\
\hline \multicolumn{8}{|l|}{ Highest completed education: } \\
\hline Compulsory school & 0.095 & $(0.294)$ & 0.126 & $(0.334)$ & 0.064 & $(0.246)$ & 0.143 \\
\hline Vocational school & 0.365 & $(0.483)$ & 0.295 & $(0.458)$ & 0.436 & $(0.499)$ & 0.043 \\
\hline High school & 0.106 & $(0.308)$ & 0.137 & $(0.346)$ & 0.074 & $(0.264)$ & 0.163 \\
\hline Teaching diploma & 0.037 & $(0.189)$ & 0.021 & $(0.144)$ & 0.053 & $(0.226)$ & 0.242 \\
\hline Adv. vocational school & 0.175 & $(0.381)$ & 0.158 & $(0.367)$ & 0.191 & $(0.396)$ & 0.543 \\
\hline Univ. of applied sciences & 0.095 & $(0.294)$ & 0.116 & $(0.322)$ & 0.074 & $(0.264)$ & 0.333 \\
\hline University & 0.127 & $(0.334)$ & 0.147 & $(0.356)$ & 0.106 & $(0.310)$ & 0.397 \\
\hline Risk attitudes & 5.940 & $(2.423)$ & 5.724 & $(2.503)$ & 6.165 & $(2.330)$ & 0.259 \\
\hline Cognitive skills & 1.228 & $(1.186)$ & 1.245 & $(1.149)$ & 1.211 & $(1.228)$ & 0.722 \\
\hline \multicolumn{8}{|l|}{ Survey language: } \\
\hline German & 0.938 & $(0.242)$ & 0.929 & $(0.259)$ & 0.947 & $(0.224)$ & 0.589 \\
\hline English & 0.041 & $(0.200)$ & 0.041 & $(0.199)$ & 0.042 & $(0.202)$ & 0.964 \\
\hline Italian & 0.005 & $(0.072)$ & 0.010 & $(0.101)$ & 0.000 & $(0.000)$ & 0.324 \\
\hline French & 0.016 & $(0.124)$ & 0.020 & $(0.142)$ & 0.011 & $(0.103)$ & 0.579 \\
\hline
\end{tabular}

All variables are binary, except for age (in years), risk attitudes (from 0 "not at all willing to take risks" to 10 "fully willing to take risks"), and cognitive skills (score in the cognitive reflection test ranging from 0 to 3). Due to item non-response, 4 observations are missing for nationality and education, 11 for age, 1 for risk attitudes. The last column presents p-values for the null hypothesis of perfect randomization $\left(\chi^{2}\right.$ tests in case of binary variables and rank-sum tests in case of interval variables). 
Table A4: Descriptive statistics of total prison population based on the annual report.

\begin{tabular}{|c|c|c|}
\hline Variable & Total $(\mathrm{N}=422)$ & in $\%$ \\
\hline \multicolumn{3}{|l|}{ Nationality: } \\
\hline Swiss & 111 & $26 \%$ \\
\hline South-eastern European & 120 & $28 \%$ \\
\hline African & 72 & $17 \%$ \\
\hline Central European & 45 & $11 \%$ \\
\hline Other & 74 & $18 \%$ \\
\hline \multicolumn{3}{|l|}{ Age: } \\
\hline 29 years or younger & 122 & $29 \%$ \\
\hline $30-39$ years & 126 & $30 \%$ \\
\hline 40-49 years & 97 & $23 \%$ \\
\hline 50-59 years & 62 & $15 \%$ \\
\hline 60 years or older & 15 & $4 \%$ \\
\hline \multicolumn{3}{|l|}{ Sentence length (if known): } \\
\hline less than 6 months & 19 & $5 \%$ \\
\hline 6-12 months & 3 & $1 \%$ \\
\hline $1-2$ years & 8 & $2 \%$ \\
\hline $2-3$ years & 37 & $9 \%$ \\
\hline $3-5$ years & 69 & $16 \%$ \\
\hline $5-10$ years & 87 & $21 \%$ \\
\hline $10-20$ years & 43 & $10 \%$ \\
\hline more than 20 years & 4 & $1 \%$ \\
\hline Safe custody & 82 & $19 \%$ \\
\hline Early imprisonment & 70 & $17 \%$ \\
\hline \multicolumn{3}{|l|}{ Type of conviction: } \\
\hline Violent crimes & 121 & $29 \%$ \\
\hline Drug-related crimes & 118 & $28 \%$ \\
\hline Property crimes & 79 & $19 \%$ \\
\hline Sex crimes & 56 & $13 \%$ \\
\hline Other & 48 & $11 \%$ \\
\hline
\end{tabular}

